\title{
Proliferating Trichilemmal Tumor of the Gluteal Region of a Young Man with Spontaneous Regression
}

\author{
Saori Nagasaki' ${ }^{1}$, Shiro Niiyama1 ${ }^{*}$, Toshiaki Oharaseki², Hideki Mukai1 \\ ${ }^{1}$ Department of Dermatology, Toho University Ohashi Medical Center, Tokyo, Japan \\ ${ }^{2}$ Department of Pathology, Toho University Ohashi Medical Center, Tokyo, Japan \\ Email: sniiyama@aol.com
}

Received 11 May 2015; accepted 26 June 2015; published 29 June 2015

Copyright (C) 2015 by authors and Scientific Research Publishing Inc.

This work is licensed under the Creative Commons Attribution International License (CC BY). http://creativecommons.org/licenses/by/4.0/

c) (i) Open Access

\begin{abstract}
We describe a case of a proliferating trichilemmal tumor (PTT) on the gluteal region of a 24-yearold male, presenting as a solitary nodule with spontaneous regression. This is the first report of a case in PTT with spontaneous regression.
\end{abstract}

\section{Keywords}

Cyst, Neoplasm, Skin

\section{Introduction}

Proliferating trichilemmal tumor (PTT) is an uncommon adnexal neoplasm that probably arises from a preexisting trichilemmal cyst subsequent to trauma or inflammation; it can also occur without a preexisting cyst. We report an unusual case of a PTT which presented as a nodular tumor located on the gluteal region of a young male patient with spontaneous regression.

\section{Case Report}

A 24-year-old man presented with a 4-month history of a gradually enlarging lesion on the right gluteal region that was otherwise asymptomatic. His medical history was unremarkable, and he had no history of trauma or insect bite at the location. Physical examination showed a localized, non-painful, hard consistency nodule measuring $50 \times 30 \mathrm{~mm}$ with a $30 \times 15 \mathrm{~mm}$ ulcerative lesion (Figure 1). A skin biopsy from non-ulcerative lesion

${ }^{*}$ Corresponding author.

How to cite this paper: Nagasaki, S., Niiyama, S., Oharaseki, T. and Mukai, H. (2015) Proliferating Trichilemmal Tumor of the Gluteal Region of a Young Man with Spontaneous Regression. Modern Plastic Surgery, 5, 19-22.

http://dx.doi.org/10.4236/mps.2015.53004 
showed the tumor was well demarcated from the surrounding tissue in the dermis, and revealed masses of squamous epithelium, demonstrating trichilemmal keratinization, extensive eosinophilic amorphous ketatin, and keratin pearls (Figure 2). This was consistent with PTT.

Surprisingly, the tumor began decreasing 8 weeks after performing the skin biopsy, and the size of the ulcerated legion was $13 \times 13 \mathrm{~mm}$ in diameter (Figure 3). We excised the lesion with a $5 \mathrm{~mm}$ surgical margin. Histologically, the remaining skin legions showing spontaneous regression were replaced by granulation tissue with infiltration of inflammatory cells. The pattern of fibrosis was lamellar and pauci-cellular, with prominent sclerosis. The predominant cells of infiltrating lymphocytes were $\mathrm{CD}^{+}$and $\mathrm{CD}^{+} \mathrm{T}$ cells. The epidermis showed pseudoepitheliomatous hyperplasia near a self-resolving ulcer (Figure 4). The tumor was not found even confirmed specimens of consecutive sections. No relapse was observed during the 12-month period of follow-up.

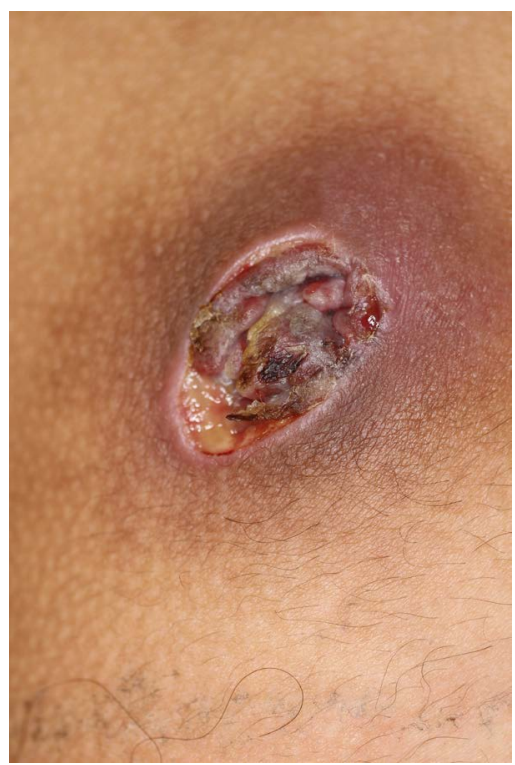

Figure 1. Nodule measuring $50 \times 30 \mathrm{~mm}$ with a $30 \times 15 \mathrm{~mm}$ ulcerative lesion on the gluteal region.

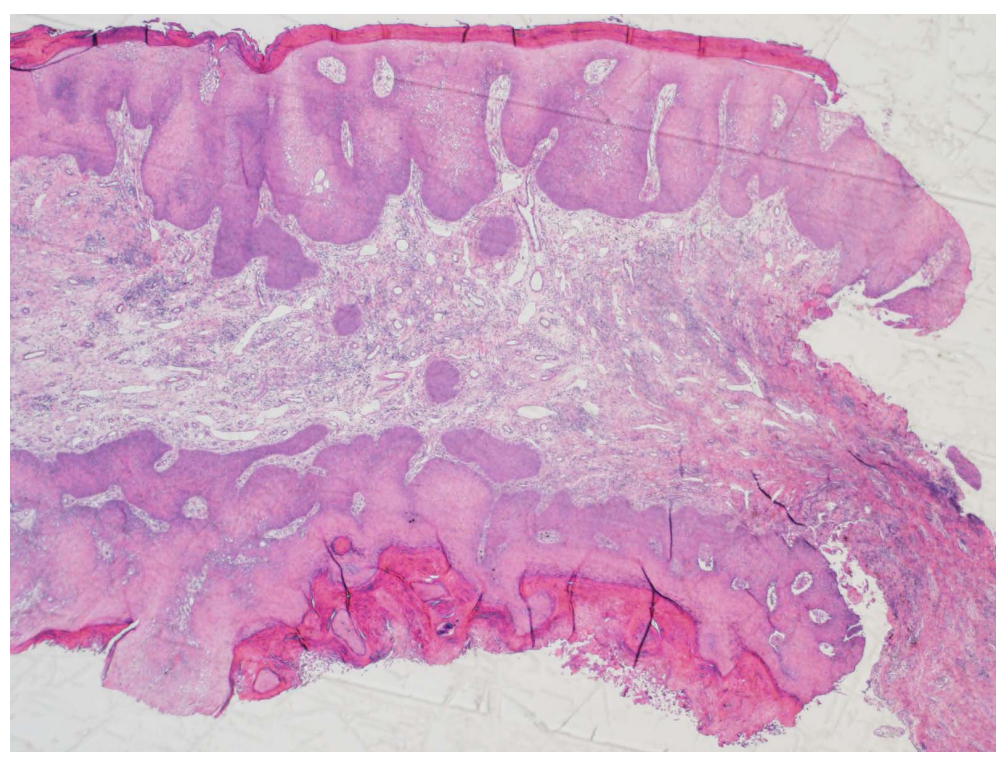

Figure 2. It revealed masses of squamous epithelium, demonstrating trichilemmal keratinization, extensive eosinophilic amorphous ketatin, and keratin pearls (Hematoxylin-eosin stain; original magnification $\times 12.5$ ). 


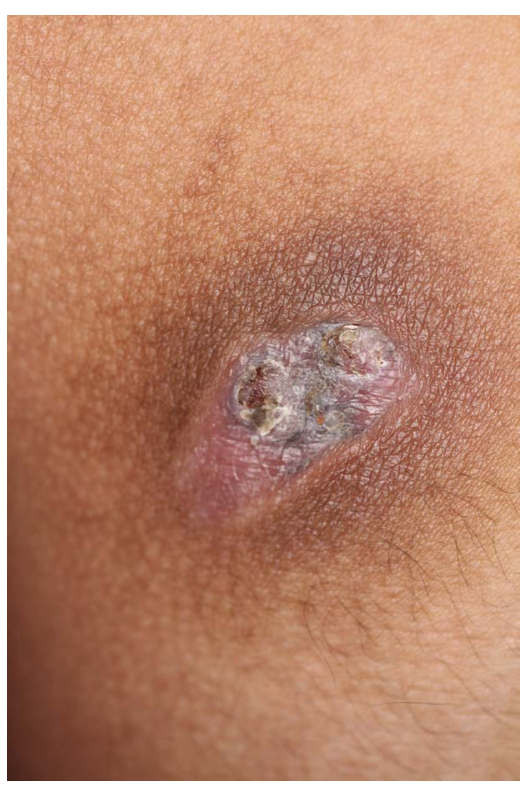

Figure 3. Eight weeks after skin biopsy, the size of the ulcerated legion was $13 \times 13 \mathrm{~mm}$ in diameter.

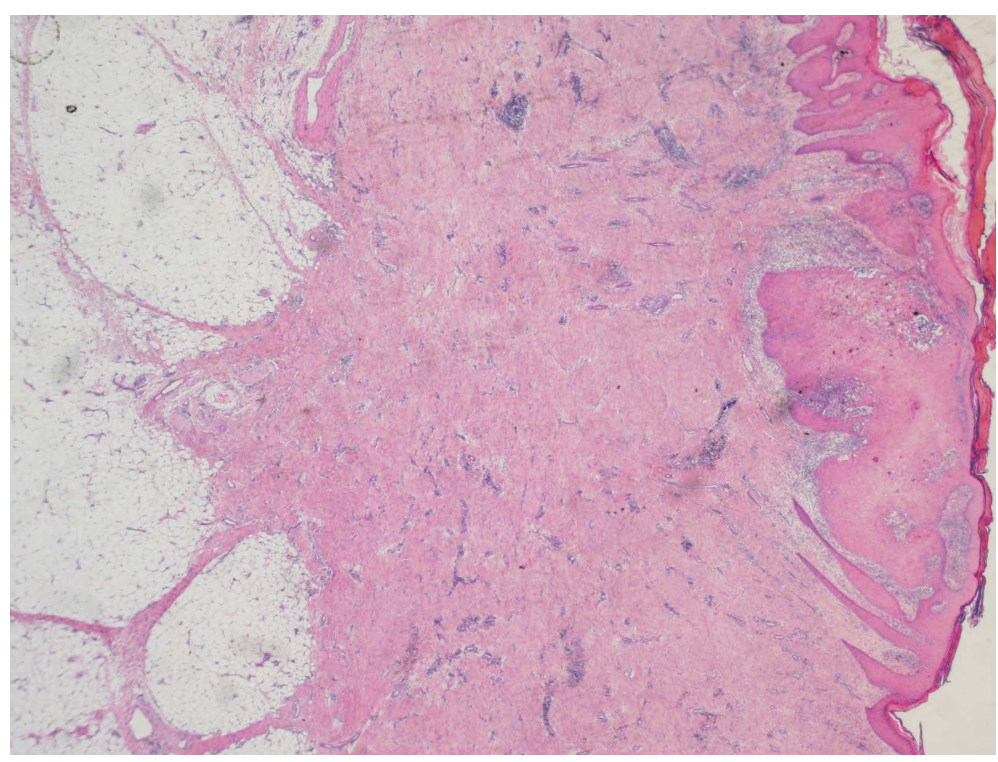

Figure 4. The remaining skin legions showing spontaneous regression were replaced by granulation tissue with infiltration of inflammatory cells (HE; $\times 12.5)$.

\section{Discussion}

About $90 \%$ of cases involve scalp lesions, described clinically as pink to reddish, subcutaneous, and cystic nodule that slowly progresses to a large, nodular mass that may ulcerate and bleed. The residual $10 \%$ of cases are found on nose, mons pubis, vulva, and buttocks [1] [2]. In more than $80 \%$ of cases, women are affected, and the average age of patients is 65 years. The tumor is characterized histologically by the proliferation of basaloid and squamous cells with abrupt trichilemmal keratinization, and varying degrees of cytologic atypia. This is a case of an uncommon tumor on a rare location of a young male, and only one similar case has ever been reported [2].

Spontaneous regression has been observed in skin lesions of melanoma, basal cell carcinoma, seborrheic keratosis, histiocytoma, and neurofibroma [3]. However, this is the first report of a case in PTT. With regard to 
cutaneous tumors, particularly melanoma, there is evidence suggesting that the immune system plays a central role in mediating tumor regression [4]. In the tumor regression area, atypical epitheloidal cells with atrophic changes were observed. The number of infiltrating cells is much higher in the lesion after regression compared with that before regression. In addition, $\mathrm{CD}^{+}$and $\mathrm{CD}^{+} \mathrm{T}$ cells have predominantly infiltrated the shrinking lesion, indicating that the immune-response has induced spontaneous regression of the tumor. Fujimura et al. [5] described a case of basal cell carcinoma with spontaneous regression and assessed the profiles infiltrating lymphocytes, which revealed an increase in effector $\mathrm{T}$ cells and a decrease in immunosuppressive cells, including regulatory $\mathrm{T}$ cells and $\mathrm{CD} 163^{+} \mathrm{M} 2$ macrophages in the tumor regressing area.

Resection of the tumor with a $1 \mathrm{~cm}$ conservative margin of normal tissue and accurate follow-up is the treatment of PTT [1]. We initially planned to perform a skin graft in our case, but because the tumor had shrunk, we just performed a simple resection. We performed surgery, because it was what the patient desired. Depending on the individual case, observing the course of patients with a PTT that spontaneously regresses would seem to be one of the treatment options.

\section{References}

[1] Karaca, S., Kulac, M., Dilek, F.H., Polat, C. and Yilmaz, S. (2005) Giant Proliferating Trichilemmal Tumor of the Gluteal Region. Dermatologic Surgery, 31, 1734-1736.

[2] Cavaleiro, L.H., Viana, F.deO., Carneiro, C.M. and Miranda, M.F. (2011) Proliferating Trichilemmal Tumor-Case Report. Anais Brasileiros de Dermatologia, 86, S190-S192. http://dx.doi.org/10.1590/S0365-05962011000700049

[3] Arpaia, N., Casssano, N., Filotico, R., Laricchia, F. and Vena, G.A. (2005) Unusual Clinical Presentation of Regression in a Congenital Melanocytic Nevus. Dermatologic Surgery, 31, 471-473. http://dx.doi.org/10.1097/00042728-200504000-00017

[4] Hunt, M.J., Halliday, G.M., Weedon, D., Cooke, B.E. and Barnetson, R.S. (1994) Regression in Basal Cell Carcinoma: An Immunohistochemical Analysis. British Journal of Dermatology, 130, 1-8. http://dx.doi.org/10.1111/j.1365-2133.1994.tb06873.x

[5] Fujimura, T., Kakizaki, A., Kambayashi, Y. and Aiba, S. (2012) Basal Cell Carcinoma with Spontaneous Regression: A Case Report and Immunohistochemical Study. Case Reports in Dermatology, 4, 125-132. http://dx.doi.org/10.1159/000339621 